\title{
PEMBERANTASAN KORUPSI DALAM KERANGKA PERSPEKTIF POLITIK HUKUM PIDANA
}

\author{
Elizabeth Ghozali \\ Fakultas Hukum Universitas Katolik Santo Thomas, Medan, Indonesia \\ Email : eghozali591@gmail.com
}

\begin{abstract}
ABSTRAK
Tujuan penelitian ini adalah untuk mengetahui perkembangan pemberantasan tindak pidana korupsi di Indonesia ditinjau dari perspektif politik hukum nasional. Penelitian yang dilakukan adalah penelitian hukum normatif yang menggunakan bahan hukum sebagai sumber utamanya dengan pendekatan perundang-undangan (statute approach), pendekatan komparatif (comparative approach), dan pendekatan konseptual (conceptual approach). Teknik analisis dimulai dengan inventarisasi (identifikasi) setelah diklasifikasikan, kemudian dianalisis secara kualitatif dengan pendekatan yuridis normatif. Hasil penelitian menunjukkan bahwa pemberantasan tindak pidana korupsi di Indonesia dalam perspektif politik hukum nasional lebih mengedepankan kepada manfaat hukum dan urgensi kebutuhan hukum dalam hal penegakan hukum dengan melakukan penyesuaian dengan kebijakan dalam Konvensi yang diratifikasi menyangkut kebijakan legislasi terkait kemungkinan-kemungkinan perumusan unsur-unsur tindak pidana korupsi dalam upaya mencegah dan memberantas korupsi di sektor swasta serta kebijakan kriminalisasi beberapa bentuk tindak pidana korupsi.
\end{abstract}

\section{Kata kunci : pemberantasan, korupsi, perspektif, politik hukum nasional}

\begin{abstract}
The purpose of this study was to determine the development of eradicating corruption in Indonesia in terms of the perspective of national legal politics. The research conducted is normative legal research that uses legal materials as its main source with a statutory approach, a comparative approach, and a conceptual approach. The analysis technique begins with an inventory (identification) after being classified, then analyzed qualitatively with a normative juridical approach. The results of the study indicate that the eradication of corruption in Indonesia in the perspective of national legal politics prioritizes the benefits of law and the urgency of the need for law in terms of law enforcement by making adjustments to the policies in the ratified Convention concerning legislative policies related to the possibilities of formulating the elements of criminal acts. corruption in an effort to prevent and eradicate corruption in the private sector as well as policies to criminalize several forms of corruption.
\end{abstract}

Keywords : eradication, corruption, national legal politics, perspective

\section{A. PENDAHULUAN}

Politik hukum suatu negara, tidak terlepas dari hukum dan keadilan serta perlindungan hak asasi manusia (HAM). Kondisi ini disebabkan karena dalam suatu negara, masyarakat dan negara itu sendiri memiliki tujuan atau cita-cita yang hendak dicapai sebagaimana tertuang dalam UUD Negara Republik Indonesia Tahun 1945 yang merupakan landasan konstitusional negara hukum Republik Indonesia. Politik hukum diartikan sebagai suatu kebijakan negara melalui badan-badan yang berwenang untuk menetapkan perangkat peraturan yang dikehendaki yang diperkirakan dapat dipergunakan untuk mengekspresikan 
apa yang terkandung dalam masyarakat dan untuk mencapai apa yang dicita-citakan. Dalam Negara Republik Indonesia, politik hukum diarahkan guna mencapai tujuan yang dicitacitakan yang tertuang dalam Pembukaan UUD 1945.

Konsep negara hukum yang dijamin secara konstitusional dalam Pasal 1 ayat (3) UUD Negara RI disepakati bersama oleh para pendiri negara (founding fathers) untuk mencegah terjadinya penyalahgunaan kekuasaan yaitu dengan membatasi terjadinya penyelahgunaan kekuasaan tersebut. Namun realitas penyalahgunaan kekuasaan (abuse of power), dan penegakan hukum (law enforcement) masih belum berjalan dengan baik dan optimal, terbukti dengan semakin maraknya tindak kekerasan dan konflik sosial dalam masyarakat dan semakin tingginya tingkat kriminalitas termasuk Korupsi, Kolusi dan Nepotisme (KKN).

Masalah krusial yang dihadapi bangsa Indonesia dewasa ini adalah masalah korupsi. Praktik tindak pidana korupsi di Indonesia, dapat dideskripsikan Foreign Affairs salah satu jurnal yang terbit di Amerika Serikat bahwa korupsi telah menjadi "way of life" di Indonesia. ${ }^{1}$ Maraknya kejahatan korupsi sebagai extra ordinary crime membutuhkan upaya yang luar biasa (extra ordinary measures) guna mencegah dan memberantasnya

Hukum merupakan norma yang mengarahkan masyarakat untuk mencapai cita-cita serta keadaan tertentu dengan tidak mengabaikan dunia nyata, dengan demikian hukum dilahirkan dengan penuh kesadaran oleh negara dan digunakan untuk mencapai tujuan tertentu ${ }^{2}$ Upaya pemberantasan tindak pidana korupsi telah dilakukan sejak awal kemerdekaan, melalui 4 (empat) kali perubahan Undang-undang Pemberantasan tindak pidana korupsi. Pertama, Peraturan Penguasa Militer untuk Daerah Kekuasaan Angkatan Darat No. Prt/PM-06/1957 tertanggal 9 April 1957 tentang Pemberantasan Korupsi, dan Prt/PM-08/1957 tentang Penilikan Harta Benda, Prt/PM-011/1957 tentang Penyitaan dan Perampasan Barang, serta Prt/Perpu-013/1958, kemudian secara lengkap dan sistematis ditetapkan kembali dengan Undang-Undang Nomor 24 Prp Tahun 1960. Kedua, pada masa pemerintahan Orde Baru, pemerintah menerbitkan Undang-undang Nomor 3 Tahun 1971 tentang Pemberantasan tindak pidana korupsi, namun gejala tindak pidana korupsi masih tetap saja bertahan. Gerakan reformasi Tahun 1998, pemerintah bersama-sama masyarakat telah melakukan upaya pemberantasan tindak pidana korupsi, melalui pembentukan UU Nomor 28 Tahun 1999 Tentang Penyelenggaraan Negara yang Bersih dan Bebas dari Korupsi, Kolusi dan Nepotisme. Ketiga, pembentukan UU Nomor 31 Tahun 1999 tentang Pemberantasan Tindak Pidana Korupsi yang diundangkan untuk menggantikan Undang-undang Nomor 3 Tahun 1971. Keempat, pembentukan UU Nomor 20 Tahun 2001 tentang Perubahan atas Undangundang Nomor 31 Tahun 1999 tentang Pemberantasan Tindak Pidana Korupsi (UU PTPK). Namun upaya pemberantasan tindak pidana korupsi melalui pembentukan perundangundangan maupun kebijakan pemerintah tersebut masih jauh dari apa yang diharapkan. Hal tersebut karena karakteristik atau modus operandi tindak pidana korupsi senantiasa berkembang sesuai dengan didukung oleh kemajuan ilmu pengetahuan dan teknologi.

Pada perkembangannya, tindak pidana korupsi menyangkut negara lain (transnasional) bahkan dewasa ini telah menjadi masalah internasional sehingga terdapat kesamaan pandang dari beberapa negara terhadap upaya pemberantasan korupsi. Hal tersebut ditandai dengan telah diadopsi nya Konvensi Perserikatan Bangsa-Bangsa tentang Anti Korupsi (United Nations Convention Againts Corruption) dan Pemerintah Indonesia telah meratifikasi konvensi tersebut dengan Undang-undang Nomor 7 Tahun 2006.

1 Didin S. Damanhuri, 2006, Korupsi. Reformasi Birokrasi dan Masa Depan Ekonomi Indonesia, Lembaga Penerbit FEUI, Jakarta, hlm. I2.

\footnotetext{
${ }^{2}$ Bambang Sunggono, 1994, Hukum dan Kebijakasanaan Publik, Sinar Grafika, Jakarta, hlm 76.
} 
Ratifikasi Konvensi Anti Korupsi (KAK) Perserikatan Bangsa-bangsa (PBB) Tahun 2003 oleh Pemerintah Indonesia mengandung arti bahwa politik hukum pemberantasan korupsi telah memasuki era baru yaitu menjadi bagian dari agenda politik hukum internasional dalam pemberantasan korupsi dengan memberikan perubahan paradigma, dari penghukuman dan penjeraan yang menjadi strategi tindakan pencegahan, penindakan, pengembalian hasil aset korupsi (asset recovery), dan kerjasama internasional. Ratifikasi terhadap KAK PBB tahun 2003 berpengaruh terhadap politik hukum nasional mengenai perspektif pemberantasan Tindak Pidana Korupsi di Indonesia dengan menyelaraskan prinsip-prinsip hukum dan ketentuan yang terdapat di dalam KAK PBB tahun 2003 menjadi latar belakang untuk menganalisis dan mengetahui perkembangan pemberantasan tindak pidana korupsi di Indonesia ditinjau dari perspektif politik hukum nasional.

\section{B. METODE PENELITIAN}

Untuk memecahkan permasalahan yang diajukan dalam penelitian ini sehingga dapat diperoleh jawaban atas permasalahan tersebut, maka jenis penelitian hukum yang dipergunakan adalah penelitian hukum normatif atau doctrinal artinya penelitian hukum yang menggunakan bahan hukum sebagai sumber utamanya. ${ }^{3}$ Pendekatan yang dipergunakan dalam penelitian ini adalah pendekatan perundang-undangan (statute approach), pendekatan komparatif (comparative approach), dan pendekatan konseptual (conceptual approach).

Setelah semua data terkumpul, maka dilakukan pengolahan data menurut pokok permasalahan dan pembahasannya. Pengolahan data pada hakikatnya merupakan kegiatan untuk mengadakan sistematisasi yang berarti membuat klasifikasi terhadap bahan-bahan hukum tersebut untuk memudahkan pekerjaan analisis dan konstruksi. ${ }^{4}$ Bahan hukum yang berhasil dikumpulkan yang terkait dengan penyusunan penelitian ini kemudian disusun secara deskriptif untuk dianalisis secara kualitatif. Teknik analisis yang akan dilakukan dalam menguji dan mencari jawaban atas permasalahan penelitian adalah, setelah data sekunder terkumpul akan dilakukan inventarisasi dan diseleksi (identifikasi) norma-norma mana yang termasuk hukum positif dan norma yang bukan norma hukum. Setelah diklasifikasikan, maka data tersebut akan dideskripsikan dan langsung dianalisis secara kualitatif dengan pendekatan yuridis normatif.

\section{PEMBAHASAN}

\section{Kebijakan Hukum Pidana Dalam Pemberantasan Tindak Pidana Korupsi}

Kebijakan hukum pidana dalam upaya pemberantasan tindak pidana korupsi sudah seharusnya diarahkan untuk mewujudkan kesejahteraan bangsa Indonesia pada masa yang akan datang. Konsep kebijakan hukum pidana yang mengutamakan keseimbangan antara pengembalian aset yang dikorupsi dan penjatuhan hukuman penjara menjadi pilihan hukum atau politik hukum dalam upaya pemberantasan tindak pidana korupsi.

Dalam sejarah perkembangannya, peraturan yang mengatur mengenai tindak pidana korupsi di Indonesia, dimulai dengan fase ketidakmampuan Tindak Pidana Jabatan (ambtsdelicten), yang diatur dalam KUHP untuk menanggulangi korupsi. Fase Keputusan Presiden Nomor 40 Tahun 1957 jo Regeling op de Staat van oorlag en van Beleg (Stb. 39 582 jo 40 - 79 Tahun 1939) tentang Keadaan Darurat Perang. Fase Keputusan Presiden Nomor 225 Tahun 1957 jo UU Nomor 74 Tahun 1957 jo UU Nomor 79 Tahun 1957 tentang Keadaan Bahaya, fase Peraturan Pengganti UU Nomor 24 Tahun 1960 tentang Pengusutan,

\footnotetext{
${ }^{3}$ Soerjono Soekanto dan Sri Mamudji, 1985, Penelitian Hukum Normatif Suatu Tinjauan Singkat, PT. Raja Grafindo Persada, Jakarta, hlm. 14.

${ }^{4}$ Soerjono Soekanto, 2012, Pengantar Penelitian Hukum, UI-Press, Jakarta, hlm. 251-252
} 
Penuntutan dan Pemeriksaan Tindak Pidana Korupsi, fase UU Nomor 3 Tahun 1971 tentang Pemberantasan Tindak Pidana Korupsi dan fase UU Nomor 31 Tahun 1999 tentang Pemberantasan Tindak Pidana Korupsi. ${ }^{5}$

Setelah itu diadakan pula pembaruan terhadap kebijakan legislasi dengan ditetapkannya UU Nomor 20 Tahun 2001 tentang Perubahan Atas UU Nomor 31 Tahun 1999 tentang Pemberantasan Tindak Pidana Korupsi. Bagian yang cukup penting dari UU Perubahan Atas Undang-Undang Nomor 31 Tahun 1999 tentang Pemberantasan Tindak Pidana Korupsi adalah mengenai perihal beban pembuktian sebagaimana dirumuskan dalam Pasal 12 A dan kebijakan untuk mengambil alih rumusan delik dalam berbagai pasal KUHP serta merumuskannya secara eksplisit sebagai bentuk tindak pidana korupsi, yang ditegaskan dalam rumusan Pasal 1 angka 2 UU Nomor 20 Tahun 2001.

Kebijakan ini diikuti dengan pernyataan tidak lagi berlakunya pasal-pasal KUHP tersebut. Pernyataan itu ditegaskan dalam ketentuan peralihan pada Pasal 43 B UU Nomor 20 Tahun 2001. Kebijakan itu dapat dianggap sebagai sesuatu yang baru, karena peraturan perundang-undangan tentang tindak pidana korupsi yang ada sebelumnya, hanya menunjuk pasal-pasal KUHP sebagai tindak pidana korupsi tanpa merumuskan norma hukumnya di dalam undang-undang tersebut. ${ }^{6}$

Disahkannya KAK PBB tahun 2003 mengingat perkembangan korupsi telah menjadi tindak pidana yang menyangkut negara lain (transnasional) bahkan dewasa ini telah menjadi masalah internasional sehingga terdapat kesamaan pandang dari beberapa negara terhadap upaya pemberantasan korupsi.

Kebijakan hukum pidana itu meliputi kebijakan kriminalisasi, yang selain merupakan penyesuaian dengan kebijakan Konvensi Anti Korupsi (KAK) PBB 2003 yang telah diratifikasi, juga merupakan upaya mewujudkan perundang-undangan pemberantasan tindak pidana korupsi yang lebih baik. Kriminalisasi dalam kepustakaan asing dikenal dengan istilah Criminalization atau Criminalisering. ${ }^{7}$ berpendapat bahwa dengan kriminalisasi dimaksudkan sebagai suatu proses penetapan suatu perbuatan orang sebagai perbuatan yang dapat dipidana. Proses ini diakhiri dengan terbentuknya undang-undang di mana perbuatan itu diancam dengan suatu sanksi yang berupa pidana.

Pada penetapan kebijakan kriminalisasi, perlu dipertimbangkan faktor-faktor berikut,

1. keseimbangan antara sarana yang digunakan dan hasil-hasil yang ingin dicapai,

2. analisis terhadap hasil yang diperoleh dalam hubungannya dengan tujuan yang hendak dicapai,

3. penilaian atau penafsiran tujuan yang ingin dicapai dalam kaitannya dengan prioritas lainnya dalam alokasi sumber daya, dan

4. pengaruh sosial dari kriminalisasi dan dekriminalisasi. Pendekatan yang berorientasi pada kebijakan cenderung menjadi pragmatis dan kualitatif serta tidak memberi kemungkinan masuknya faktor subyektif, misalnya nilai-nilai ke dalam proses pembuatan keputusan. Namun demikian pendekatan ini perlu dipertimbangkan sebagai suatu scientific device yang digunakan sebagai alternatif dari pada pendekatan emosional (the emotionally laden value judgement) oleh kebanyakan badan-badan legislasi.

Pendekatan kebijakan dalam praktik memang dirasakan lamban, karena berbagai

${ }^{5}$ Lilik Mulyadi, 2000, Tindak Pidana Korupsi (Tinjauan Khusus Terhadap Proses Penyidikan, Citra Aditya Bakti, Bandung, hlm. 2 - 3.

${ }^{6}$ Elwi Danil, 2012, Korupsi: Konsep, Tindak Pidana dan Pemberantasannya, Rajawali Pers, Jakarta, hlm. $55-56$.

${ }^{7}$ Sudarto., 1986, Op.Cit, hlm. 32. 
kendala alokasi sumber daya dalam mendukung dilakukannya proses ilmiah, sehingga proses kriminalisasi sering berakibat timbulnya krisis kelebihan kriminalisasi (the crisis of overcriminalization) dan krisis kelampauan batas hukum pidana (the crisis of overreach of the criminal law). Hal pertama menyangkut melimpahnya jumlah perbuatan yang dikriminalisasi secara emosional, sedangkan yang kedua menyangkut usaha pengendalian perbuatan tersebut dengan penggunaan sanksi yang tidak efektif.

Dengan demikian dalam konteks tersebut, ditekankan agar kebijakan kriminal senantiasa rasional sesuai dengan pengertiannya yakni a rational total of the responses to crime. Penggunaan pidana sebagai alat pencegah yang ekonomis harus memenuhi beberapa syarat yaitu, pemidanaan sungguh-sungguh dapat mencegah terjadinya tindak pidana, pemidanaan tidak menimbulkan keadaan yang lebih merugikan bila dibandingkan dengan keadaan jika pidana itu tidak dikenakan dan tidak ada cara lain yang dapat mencegah secara efektif dengan kerugian (bahaya) yang lebih kecil.

Selain itu, kepentingan atau nilai-nilai yang ingin dilindungi oleh hukum pidana perlu dipertimbangkan yaitu: (a) pemeliharaan tertib masyarakat; (b) perlindungan warga dari kejahatan, kerugian, atau bahaya-bahaya; (c) memasyarakatkan kembali (resosialisasi) para pelanggar hukum; dan (d) memelihara dan mempertahankan integritas pandangan dasar mengenai keadilan sosial, martabat kemanusiaan, dan keadilan individu.

Sebagaimana telah dikemukakan sebelumnya, bahwa perundang-undangan korupsi telah dibuat sejak tahun 1960 dan telah diubah sebanyak empat kali, dan terakhir kalinya dengan UU Nomor 20 Tahun 2001 tentang Perubahan UU Nomor 31 Tahun 1999 tentang Pemberantasan Tindak Pidana Korupsi. Saat inipun pemerintah sedang mempersiapkan suatu draft Rancangan UU Pemberantasan Korupsi baru untuk menggantikan UU Nomor 31 Tahun 1999 dengan penyesuaian terhadap Konvensi Anti Korupsi PBB Tahun 2003, yang telah disahkan dengan UU Nomor 7 Tahun 2006.

Patut diakui bahwa korupsi bukan lagi menjadi masalah nasional suatu negara saja, tetapi telah bergeser menjadi masalah internasional, karena korupsi telah menembus batasbatas negara dan dapat dikatakan sebagai kejahatan transnasional. Oleh karena itu, Romli Atmasasmita, ${ }^{8}$ menyebutkan bahwa pembentukan dan sinkronisasi peraturan perundangundangan baru yang secara khusus ditujukan untuk pencegahan dan pemberantasan korupsi transnasional tampaknya sangat diperlukan atas dasar pertimbangan sebagai berikut:

Pertama: KAK PBB 2003 secara substansial telah banyak mengadopsi sistem hukum "Common Law" dibandingkan dengan sistem hukum "Civil Law". Hal ini terbukti dengan beberapa pernyataan dalam mukadimah yang menetapkan korupsi sebagai kejahatan transnasional dan dihubungkan dengan implikasi luas terhadap pembangunan berkelanjutan dengan konsekuensi logis bahwa aspek pengembalian asset hasil korupsi sebagai asset pembangunan yang tiada ternilai. Dalam kaitan ini sesungguhnya tindakan pengembalian asset bukan lagi bersifat kepidanaan belaka melainkan sudah memasuki rezim hukum keperdataan yang lebih mengutamakan prinsip "win-win solution" daripada prinsip "win-lose solution".

Kedua Rezim hukum pidana konvensional tidak mengakui pola penyelesaian "win-win solution", kecuali tujuan pembalasan, penjeraan dan tujuan kemanfaatan bagi masyarakat luas di mana pertanggungjawaban pidana diletakkan kepada individu pelaku kejahatan; dan baru pada tahun 1990-an telah diakui bahwa korporasi adalah subjek tindak pidana korupsi

Kedua pertimbangan di atas, menunjukkan bahwa sudah terjadi pergeseran pandangan

8 Romli Atmasasmita, Strategi dan Kebijakan Pemberantasan Korupsi Pasca Konvensi PBB Menentang Korupsi Tahun 2003, Makalah disampaikan pada ceramah "Convention Against Corruption" diselenggarakan oleh Mahkamah Agung tanggal 30 Oktober 2004. 
terhadap hakekat dan makna penyelesaian kasus korupsi yang bersifat lintas batas Negara. Korupsi yang semula merupakan "individual crime" atau "white collar crime" pada saat ini telah merupakan "organized crime" dan "systematic white collar crime". Kualifikasi kejahatan tersebut sekaligus menunjukkan bahwa penegakan hukum terhadap korupsi bukan lagi tugas yang mudah, akan tetapi tugas yang sangat kompleks dan melibatkan sistem birokrasi yang bergandengan tangan erat dengan sektor swasta. Hasil penelitian mengenai "corporate crime" yang merugikan Negara menunjukkan bahwa prinsip "win-lose" tidak lagi ampuh dibandingkan dengan prinsip "win-win" dalam menyelesaikan kasus-kasus "corporate crime" yang merugikan Negara.

Sehubungan dengan tindak pidana korupsi akhir abad 20 sudah merupakan "organized crimes" sebagaimana diakui dalam Kovensi UNTOC Palermo, maka telah terjadi pergeseran paradigma dari "corporate crime of corruption" menjadi "organized crime of corruption"; suatu pergeseran bentuk baru dari subjek pelaku tindak pidana korupsi yang bersifat transnasional. Bentuk dan modus operandi baru dalam perkembangan tindak pidana korupsi tersebut belum dapat sepenuhnya dijangkau oleh UU Nomor 31 tahun 1999 juncto Undangundang Nomor 20 tahun 2001 tentang Perubahan UU Nomor 31 tahun 1999. Selain itu, "organized crime of corruption" yang bersifat transnasional memerlukan payung hukum yang dapat menjangkau ke luar batas-batas territorial.

Seirama dengan uraian di atas, pendapat Indriyanto Seno Adji tentang pendekatan sistemik (systemic approach) untuk meminimalisasi korupsi, layak untuk dipertimbangkan. Pendekatan sistemik sebagaimana yang ditawarkan oleh Seno Adji ${ }^{9}$ meliputi 2 (dua) upaya, yaitu: (1) Upaya pendekatan sistematis terhadap pemberantasan tindak pidana korupsi; dan (2) Upaya perbaikan perundang-undangan dalam mengantisipasi kesulitan pembuktian.

Pada upaya pertama, pemberantasan tindak pidana korupsi tidak semata-mata dilakukan dengan memaksimalisasi lembaga peradilan sebagai suatu sub-sistem, namun terkait erat dengan keterpaduan aparat penegak hukum, yang pada hakekatnya kait-mengkait dan saling mempengaruhi satu sama lain sebagai suatu sistem. Oleh karenanya dibutuhkan kesamaan visi, koordinasi yang serasi, dan kerjasama yang saling memperkuat dan juga saling mengawasi (check and balance) ke arah perwujudan visi tersebut. Dalam kaitan ini, pemahaman kebijakan hukum pidana pemberantasan korupsi seharusnya menjamin visi yang sama bagi segenap aparat penegak hukum, yang harus diimplementasikan di dalam fungsinya masing-masing, termasuk koordinasi dan kerjasama yang saling memperkuat tersebut.

Selanjutnya pada tataran upaya yang kedua, pembenahan struktur hukum diarahkan kepada segala lembaga (organ) penyelenggara Sistem Peradlan yang dapat meminimalisasi KKN melalui perbaikan birokrasi, struktur peradilan dan pengawasan. Sementara itu, pembenahan substansi hukum meliputi perangkat ketentuan hukum normatif (legal reform), pola, kehendak dan perilaku masyarakat yang ada di dalam sistem hukum tersebut. Akhirnya, pembenahan budaya hukum diorientasikan kepada bagaimana masyarakat menganggap ketentuan hukum itu sebagai civic minded (berpihak kepada kepentingan rakyat), sehingga masyarakat taat dan sadar akan pentingnya hukum tersebut.

Dengan mengacu kepada uraian tersebut di atas, maka pendekatan sistemik dalam pemberantasan tindak pidana korupsi di Indonesia, meliputi kebijakan legislasi, yang meliputi kemungkinan-kemungkinan perumusan unsur-unsur tindak pidana korupsi, pengaturan ancaman pidana (sanksi), dan pengembalian aset hasil korupsi serta pengelolaan aset yang telah disita (dirampas).

Mengingat bahwa pelaku tindak pidana korupsi dapat digolongkan sebagai orang-orang

9 Indriyanto Seno Adji., 2006, Korupsi dan Pembalikan Beban Pembuktian, Penerbit Konsultan Hukum Prof. Seno Adji dan Rekan, Jakarta, hlm.2-3. 
yang rasional (rational-amoral criminals) yang senantiasa mengkalkulasikan risiko (risk) dan keuntungan (benefit) dari hasil tindakannya, maka kebijakan hukum pidana pemberantasan tindak pidana korupsi yang efektif seyogyanya menyentuh langsung pada sasaran ini. ${ }^{10}$

Ini berarti penggunaan hukum pidana di dalam memberantasan tindak pidana korupsi harus diwujudkan melalui kebijakan yang: (1) memperkecil insentif keuntungan pelaku; dan (2) memperbesar kemungkinan pelaku dapat dituntut dan dijatuhi hukuman.

\section{Kebijakan Kriminalisasi Tindak Pidana Korupsi}

UU Nomor 31 Tahun 1999 jo. UU Nomor 20 Tahun 2001 tentang Pemberantasan Tindak Pidana Korupsi membedakan 2 (dua) jenis tindak pidana yang didasarkan pada historis yakni jenis tindak pidana yang dirumuskan oleh pembuat undang-undang (peraturan) semenjak diberlakukannya Peraturan Penguasa Perang Pusat Tahun 1957-1958, dan rumusan tindak pidana yang ditarik dari pasal-pasal KUHP dengan berbagai perbaikan di kemudian hari.

Rumusan tindak pidana (delik) kelompok pertama menyangkut kerugian keuangan negara dan atau perekonomian negara (Pasal 2 dan 3 UU No.31/1999 sekarang), sedangkan rumusan delik yang ditarik dari KUHP lebih bernuansa penyuapan, penggelapan dalam jabatan, pemerasan dan seterusnya.

Seiring dengan perkembangan pembangunan di Indonesia, berkembang pula bentukbentuk kejahatan ditengah-tengah masyarakat. Dalam upaya menanggulangi kejahatankejahatan tersebut dilakukan suatu kebijakan kriminal/politik kriminal (criminal policy), yang meliputi kebijakan secara terpadu antara upaya penal dan non penal yang dapat diintegrasikan satu dengan yang lainnya.

Pada hakekatnya, dengan diterapkan politik dalam penegakan hukum menjadikan hukum mencapai tujuan negara dalam arti semua instrumen hukum harus berdasarkan pada tujuan Negara oleh karena politik hukum merupakan legal policy atau garis (kebijakan) resmi tentang hukum yang akan diberlakukan baik dengan pembuatan hukum baru maupun dengan penggantian hukum lama, dalam rangka mencapai tujuan negara. ${ }^{11}$

Politik hukum pidana berarti melaksanakan dengan mengadakan pemilihan untuk mencapai hasil perundang-undangan pidana yang paling baik, dalam arti memenuhi syarat keadilan dan daya guna. ${ }^{12}$ Dengan demikian, sebagai bagian dari kebijakan hukum, maka politik hukum pidana mengandung arti bagaimana mengusahakan atau membuat dan merumuskan suatu perundang-undangan pidana yang baik. Ini berarti bahwa kebijakan hukum pidana menetapkan pilihan-pilihan untuk mencapai hasil perundang-undangan pidana yang paling baik, dalam arti memenuhi syarat keadilan dan daya guna (efektif dan efisien) dalam rangka penanggulangan tindak pidana korupsi.

Upaya penanggulangan kejahatan dengan hukum pidana, pada hakikatnya juga merupakan bagian dari usaha penegakan hukum (khususnya penegakan hukum pidana). Oleh karena itu, sering pula dikatakan bahwa kebijakan hukum pidana, juga merupakan bagian dari kebijakan penegakan hukum (law enforcement policy). Selain itu, usaha penanggulangan kejahatan melalui pembuatan undang-undang (hukum) pidana, pada hakikatnya juga merupakan bagian integral dari usaha perlindungan masyarakat (social defence) dan usaha mencapai kesejahteraan masyarakat (social welfare). Oleh karena itu, politik hukum pidana

${ }^{10}$ Robert Cooter dan Thomas Uleen, 2000, dalam bukunya, An Introduction of Law and Economics, Edisi ke-3, Addison-Wesley, hlm. 435.

11 Mahfud M.D., 2010, Membangun Politik Hukum Menegakkan Konstitusi, PT Raja Grafindo Persada, Jakarta, hlm.5.

${ }^{12}$ Sudarto, 1986, Hukum dan Hukum Pidana, Alumni, Bandung, hlm. 161. 
merupakan bagian integral dari kebijakan sosial (social policy) yang diartikan sebagai segala usaha yang rasional untuk mencapai kesejahteraan masyarakat dan sekaligus mencakup perlindungan masyarakat. Kebijakan sosial (social policy) dapat diartikan sebagai segala usaha yang rasional untuk mencapai kesejahteraan masyarakat dan sekaligus mencakup perlindungan masyarakat. Jadi, dalam pengertian social policy, sekaligus tercakup di dalamnya social welfare policy dan social defence policy. ${ }^{13}$

Tindak Pidana Korupsi berasal dari kata tindak pidana" dan korupsi.Tindak pidana diartikan dengan perbuatan yang dilarang oleh peraturan hukum pidana dengan sanksi bagi siapa saja yang melanggarnya. Istilah korupsi berasal dari bahasa Latin Corruptie atau Corruptus yang diartikan penyuapan dan merusak.

Secara harfiah, arti dari "korupsi" dapat berupa kejahatan, kebusukan, dapat disuap, tidak bermoral, kebejadan dan ketidakjujuran. ${ }^{14}$ Korupsi juga diartikan sebagau perbuatan yang kenyataannya menimbulkan keadaan yang bersifat buruk. Perilaku yang jahat dan tercela, atau kebejadan moral. Penyuapan dan bentuk-bentuk ketidakjujuran. ${ }^{15}$

Dalam pengertian Yuridis-Formal, tindak pidana korupsi terdapat dalam Bab II tentang Tindak Pidana Korupsi Pasal 2 sampai dengan Pasal 20, Bab II tentang Tindak Pidana Lain yang berkaitan dengan Tindak Pidana Korupsi Pasal 21 sampai dengan Pasal 24 UU Nomor 31 Tahun 1999 jo UU Nomor 20 Tahun 2001.

Definisi korupsi dijelaskan secara lengkap pada 13 (tiga belas) buah pasal di dalam UU Nomor 31 Tahun 1999 jo UU Nomor 20 Tahun 2001. Berdasarkan pasal-pasal tersebut, korupsi dirumuskan ke dalam 30 (tiga puluh) bentuk/jenis tindak pidana korupsi yang pada dasarnya dapat dikelompokkan sebagai berikut:

a. Menyangkut kerugian keuangan negara

b. Suap menyuap (Pasal 5, 6, 11, 12, dan 13);

c. Penggelapan dalam jabatan (Pasal 8, 9, dan 10);

d. Pemerasan (Pasal 12);

e. Perbuatan curang (Pasal 7 dan 12);

f. Benturan kepentingan dalam pengadaan barang dan jasa (Pasal 12 huruf i);

g. Gratifikasi (Pasal 12 B jo. Pasal 12 C).

Selain pasal-pasal tindak pidana korupsi yang sudah disebutkan di atas, masih ada tindak pidana lain yang berkaitan dengan tindak pidana korupsi, yaitu:

a. Merintangi proses pemeriksaan perkara korupsi;

b. Tidak memberi keterangan atau memberi keterangan yang tidak benar;

c. Bank yang tidak memberi rekening tersangka;

d. Saksi atau ahli yang tidak memberi keterangan atau memberi keterangan palsu;

e. Orang yang memegang rahasia jabatan tidak memberi keterangan atau memberi keterangan palsu;

f. Saksi yang membuka identitas pelapor.

Dari perspektif Indonesia, yang perlu dilakukan dalam rangka Konvensi tersebut adalah pertama, melakukan proses penyesuaian (harmonisasi) peraturan perundangan yang sudah ada dengan prinsip-prinsip Konvensi, dan yang kedua, melakukan pembentukan peraturan perundang-undangan baru untuk mendukung prinsip-prinsip yang terkandung dalam

${ }^{13}$ Muladi dan Barda Nawawi Arief., 1992, Teori-teori dan Kebijakan Pidana, Alumni, Bandung, hlm.

${ }^{14}$ S. Wojowasito \& W.J.S. Poerwadarminta., 1991, Kamus Lengkap Inggris-Indonesia, IndonesiaInggris, Hasta, Bandung, hlm. 33 dan hlm. 150

15 Soedjono Dirdjosisworo, 2000, Fungsi Perundang-Undangan Pidana dalam Penanggulangan Korupsi di Indonesia, Sinar Baru, Bandung, hlm. 17 
konvensi, namun belum tertampung dalam peraturan yang telah ada. Kedua upaya tersebut perlu dilandasi oleh suatu konsep kebijakan hukum pidana yang mantik agar tidak merupakan upaya tambal sulam yang saling kontradiktif, dan kurang berorientasi pada tujuan yang jelas.

Dengan telah diratifikasi dan disahkannya KAK PBB 2003 dengan Undang-Undang Nomor 7 Tahun 2006, maka UU Nomor 31 Tahun 1999 jo. UU Nomor 20 Tahun 2001 perlu penyesuaian seperlunya dengan isi kebijakan konvensi tersebut. Hal ini antara lain menyangkut kebijakan kriminalisasi yang dianjurkan (mandatory dan optional) oleh konvensi tersebut.

Negara-negara peserta dianjurkan oleh konvensi untuk mengkriminalisasi perbuatanperbuatan yang dipandang sebagai perbuatan korupsi. Akan tetapi rumusan delik yang dianjurkan tersebut, berbeda dengan rumusan di dalam UU Nomor 31 Tahun 1999, sehingga memerlukan berbagai penyesuaian antara lain di dalam konvensi Pasal 15 butir a digunakan istilah "pejabat publik" sebagai penerima dan yang melakukan penyuapan aktif dengan rumusan bahwa: "dengan sengaja melakukan tindakan-tindakan janji, menawarkan atau memberikan kepada seorang pejabat publik, secara langsung atau tidak langsung suatu keuntungan yang tidak layak, untuk orang lain atau badan hukum agar pejabat tersebut bertindak atau menahan diri dari melakukan (tidak melakukan) suatu tindakan dalam melaksanakan tugas resminya".

Hal tersebut di atas, jelas berbeda rumusannya dengan Pasal 209 dan 210 KUHP, yang sekarang telah diadopsi menjadi delik korupsi pada Pasal 12 UU PTPK. Rumusan Konvensi memasukkan perbuatan "menawarkan" yang tidak terdapat di dalam Pasal 209 dan 210 KUHP. Objek suap dalam rumusan KUHP tersebut berupa suatu pemberian (gift) atau janji (belofte) sedangkan di dalam rumusan Konvensi dirumuskan sebagai suatu "keuntungan yang tidak layak" (an undue advantage) yang artinya jelas lebih luas. Pejabat publik tersebut dalam "menjalankan tugas resminya," sedangkan dalam Pasal 209 KUHP dirumuskan dengan perkataan "dalam jabatannya" (in zijn bediening). Antara pengertian "menjalankan tugas resmi" (official duty) dan "dalam jabatannya" (in zijn bedizening) tersebut memang sangat mirip, namun pengertian "menjalankan tugas resminya" masih lebih luas.

Selain penyuapan terhadap pejabat publik nasional, di dalam Pasal 15 Konvensi, Pasal 16 juga mengatur tentang penyuapan terhadap pejabat publik asing (foreign public officials) dan pejabat publik organisasi internasional (officials public international organizations). Pasal 17 mengenai penggelapan, penyelewengan atas pengalihan kekayaan dengan cara lain oleh pejabat publik, tampaknya mirip dengan Pasal 415 KUHP yang sudah menjadi Pasal 8 Undang-undang Nomor 31 Tahun 1999. Akan tetapi perbedaan mendasar muncul karena objek yang digelapkan di dalam Pasal 415 KUHP itu, haruslah berupa "uang" atau "kertas berharga uang", sedangkan di dalam Pasal 17 konvensi ini selain dana publik atau perorangan, surat berharga, juga segala yang bernilai (any other thing of value) yang dipercayakan kepada pejabat publik tersebut. Di dalam Pasal 415 KUHP, digunakan rumusan "yang disimpan karena jabatannya", yang berarti bahwa pada umumnya ditujukan kepada bendaharawan, sedangkan di dalam Konvensi dipakai rumusan" yang dipercayakan kepada pejabat publik karena kedudukannya" (entrusted to the public official by virtue of his or her position). Pengertian rumusan "yang dipercayakan kepada pejabat publik karena kedudukannya" jelas lebih luas dari pada rumusan "yang disimpan karena jabatannya".

Ketentuan yang belum diatur, bahkan belum dikenal dalam perundang-undangan korupsi di Indonesia adalah apa yang ditemukan dalam Pasal 18 Konvensi, mengenai "memperdagangkan pengaruh" (trading of influence). Namun jika diteliti rumusannya mirip dengan rumusan delik penyuapan dalam perundang-undangan Indonesia yakni: "perbuatan dilakukan dengan sengaja, ....menjanjikan, menawarkan atau memberikan kepada seorang pejabat publik atau orang lain secara langsung atau tidak langsung, suatu keuntungan yang 
tidak semestinya (tidak layak), agar pejabat publik itu atau orang itu menyalahgunakan pengaruhnya yang nyata atau yang diperkirakan, dengan maksud untuk memperoleh dari otoritas administrasi atau otoritas publik dari negara peserta, suatu keuntungan yang tidak semestinya (layak) bagi penganjur yang asli dari tindakan itu atau orang lain. ${ }^{16}$

Pasal 19 Konvensi mengkriminalisasi perbuatan penyalahgunaan fungsi (abuse of function), yaitu kejahatan yang dilakukan dengan sengaja menyalahgunakan fungsi atau kedudukan (abuse of functions or position) dari pegawai publik. Pasal ini dapat dikaitkan dengan Pasal 35 Konvensi yang menentukan bahwa badan-badan atau orang-orang yang menderita kerugian sebagai akibat suatu perbuatan korupsi mempunyai hak untuk mengajukan tuntutan hukum terhadap pihak yang bertanggung jawab atas timbulnya kerugian tersebut agar mendapat kompensasi (ganti kerugian). Kompensasi atau ganti kerugian tidak hanya ditujukan kepada negara tetapi juga kepada pihak swasta.

Perbuatan-perbuatan yang berkaitan dengan korupsi seperti money laundering hasil kejahatan juga dikriminalisasi oleh konvensi, sebagaimana yang diatur dalam Pasal 23 dan Pasal 24 yakni, "menyembunyikan atau terus menerus menahan kekayaan padahal diketahui bahwa kekayaan itu berasal dari salah satu delik yang tercantum dalam konvensi". Sementara Pasal 25 mengkriminalisasi pula perbuatan yang menghalang-halangi proses peradilan (obstruction of justice).

Berbeda dengan UUPTPK yang sekarang ini berlaku, suap-menyuap di kalangan swasta pun dalam kegiatan ekonomi, keuangan atau perdagangan dikriminalisasi oleh Konvensi (Pasal 21). Begitu pula penggelapan di sektor swasta dalam kegiatan ekonomi, keuangan atau perdagangan (Pasal 22). Hal ini didasari pemikiran bahwa pencegahan dan pemberantasan korupsi di sektor swasta sama pentingnya dengan pemberantasan korupsi oleh dan atau yang melibatkan aparat pemerintah. Sektor swasta adalah supply side dari korupsi, sementara demand sidenya adalah aparat pemerintah (pejabat publik). Apabila supply side dari perbuatan korupsi dapat dikendalikan, maka diharapkan akan terjadi penurunan tingkat korupsi pada demand side yang lainnya.

Konsep kebijakan yang diperkenalkan oleh KAK PBB tersebut berupaya mencegah dan memberantas korupsi di sektor swasta, akan membawa paradigma baru bagi pemberantasan korupsi di Indonesia, yang selama ini hanya menyentuh kasus-kasus korupsi yang terkait dengan sektor publik (pemerintah), atau berkenaan dengan kerugian negara dan melibatkan aparatur pemerintah. Konvensi menegaskan agar setiap negara peserta wajib mengambil tindakan untuk mencegah korupsi yang melibatkan sektor swasta, yaitu dengan jalan meningkatkan standar akuntansi dan audit di sektor swasta serta menerapkan sanksi baik perdata, administratif maupun pidana.

Kebijakan kriminalisasi juga mencakup perbuatan yang dengan sengaja dilakukan dalam melaksanakan kegiatan ekonomi, keuangan atau perdagangan yang menjanjikan, menawarkan atau memberikan secara langsung atau tidak langsung suatu keuntungan yang tidak semestinya kepada seseorang yang memimpin atau bekerja pada suatu badan di sektor swasta untuk dirinya sendiri atau untuk orang lain agar ia dengan melanggar tugas-tugasnya melakukan sesuatu atau menahan diri dari melakukan sesuatu tindakan.

Berbeda dengan rumusan Pasal 2 UUPTPK, karena di dalam Pasal 2 UUPTPK termasuk juga memperkaya orang lain atau suatu korporasi. Dalam Konvensi ukuran memperkaya dalam konvensi ialah suatu kenaikan yang berarti aset seorang pejabat publik yang tidak dapat dijelaskan secara masuk akal berkaitan dengan pendapatannya yang sah. Harus ada perhitungan kekayaan pejabat publik itu sebelum menjabat dan sesudah menjabat,

${ }^{16}$ Andi Hamzah, 2006, Pemberantasan Korupsi; Melalui Hukum Pidana Nasional dan Internasional, Edisi Revisi, PT RajaGrafindo Persada, Jakarta, hlm. 242-243. 
serta dalam priode tertentu dalam masa jabatannya misalnya dalam waktu 3 (tiga) tahun. Perhitungan demikian, tidak mungkin dilakukan terhadap aset milik swasta.

Konvensi juga tidak menyebut sama sekali tentang "kerugian negara", sehingga pejabat publik yang memperkaya diri secara melawan hukum, tidak perlu dibuktikan "telah" merugikan atau "dapat" merugikan keuangan negara. Dengan demikian dapat disimpulkan bahwa, perbuatan merugikan keuangan swasta pun terjaring dalam rumusan perbuatan demikian.

\section{KESIMPULAN}

Pemberantasan tindak pidana korupsi di Indonesia dalam perspektif politik hukum nasional lebih mengedepankan kepada manfaat hukum dan urgensi kebutuhan hukum dalam hal penegakan hukum. Pembaharuan hukum dimaksud dikaitkan dengan keikutsertaan Indonesia dalam meratifikasi Konvensi Anti Korupsi PBB 2003, sehingga perlu penyesuaian seperlunya dengan isi kebijakan konvensi tersebut, antara lain menyangkut kebijakan legislasi terkait kemungkinan-kemungkinan perumusan unsur-unsur tindak pidana korupsi, pengaturan ancaman pidana (sanksi), dan pengembalian aset hasil korupsi serta pengelolaan aset yang telah disita (dirampas) terutama dalam upaya mencegah dan memberantas korupsi di sektor swasta serta kebijakan kriminalisasi beberapa bentuk tindak pidana korupsi.

\section{E. SARAN}

Kebijakan kriminalisasi tindak pidana korupsi yang akan datang perlu direvisi dan penyesuaian, meliputi bentuk penyuapan (bribery) baik yang dilakukan secara aktif maupun secara pasif, baik yang dilakukan oleh pejabat publik domestik maupun asing, serta penyuapan di sektor swasta, serta bentuk perbuatan pejabat publik yang memperdagangkan pengaruh (trading influence), dan pemerasan oleh pejabat publik dengan menggunakan pengaruh jabatannya (racketeering influence) dan pemilikan/pertambahan harta kekayaan secara signifikan yang tidak dapat dijelaskan asal-usulnya secara sah (illicit enrichment).

\section{DAFTAR PUSTAKA}

Atmasasmita, Romli, Strategi dan Kebijakan Pemberantasan Korupsi Pasca Konvensi PBB Menentang Korupsi Tahun 2003, Makalah disampaikan pada ceramah "Convention Against Corruption" diselenggarakan oleh Mahkamah Agung tanggal 30 Oktober 2004.

Barda Nawawi Arief., 1996, Bunga Rampai Kebijakan Hukum Pidana, Citra Aditya Bakti, Bandung.

Butarbutar, Elisabeth, N., 2018, Metode Peneltian Hukum, Langkah-Langkah untuk Menemukan Kebenaran dalam Ilmu Hukum, Cetakan Kesatu, PT Refika, Bandung.

Cooter, Robert dan Thomas Uleen., 2000, An Introduction of Law and Economics, Edisi ke-3, Addison-Wesley.

Damanhuri, Didin S., 2006, Korupsi. Reformasi Birokrasi dan Masa Depan Ekonomi Indonesia, Lembaga Penerbit FEUI, Jakarta.

Danil., Elwi, 2012, Korupsi: Konsep, Tindak Pidana dan Pemberantasannya, Rajawali Pers.

Dirdjosisworo, Soedjono, 2000, Fungsi Perundang-Undangan Pidana dalam Penanggulangan Korupsi di Indonesia, Sinar Baru, Bandung.

Hamzah, Andi, 2006, Pemberantasan Korupsi; Melalui Hukum Pidana Nasional dan Internasional, Edisi Revisi, PT RajaGrafindo Persada, Jakarta

Mahfud M.D., 2010, Membangun Politik Hukum Menegakkan Konstitusi, PT Raja Grafindo Persada, Jakarta. 
Muladi dan Barda Nawawi Arief., 1992, Teori-teori dan Kebijakan Pidana, Alumni, Bandung.

Mulyadi, Lilik, 2000, Tindak Pidana Korupsi (Tinjauan Khusus Terhadap Proses Penyidikan, Citra Aditya Bakti, Bandung.

Seno Adji, Indriyanto, 2006, Korupsi dan Pembalikan Beban Pembuktian, Penerbit Konsultan Hukum Prof. Seno Adji dan Rekan, Jakarta.

Soekanto, Soerjono. 2012, Pengantar Penelitian Hukum, UI-Press, Jakarta

Soekanto, Soerjono, dan Sri Mamudji, 1985, Penelitian Hukum Normatif Suatu Tinjauan Singkat, PT. Raja Grafindo Persada, Jakarta.

Sunggono, Bambang, 1994, Hukum dan Kebijakasanaan Publik, Sinar Grafika, Jakarta S. Wojowasito \& W.J.S. Poerwadarminta., 1981, Kamus Lengkap Inggris-Indonesia, Indonesia-Inggris, Hasta, Bandung.

Tirtaamidjaja, MH., 2005, Pokok-Pokok Hukum Pidana, Edisi Revisi, Fasco, Jakarta.

Wojowasito, S \& W.J.S. Poerwadarminta., 1991, Kamus Lengkap Inggris-Indonesia, Indonesia-Inggris, Hasta, Bandung. 